This item was submitted to Loughborough's Research Repository by the author.

Items in Figshare are protected by copyright, with all rights reserved, unless otherwise indicated.

\title{
Newspaper response to the Edinburgh congestion charging proposals
}

PLEASE CITE THE PUBLISHED VERSION

PUBLISHER

(C) Elsevier

LICENCE

CC BY-NC-ND 4.0

\section{REPOSITORY RECORD}

Ryley, Tim, and Nathalia Gjersoe. 2019. "Newspaper Response to the Edinburgh Congestion Charging Proposals". figshare. https://hdl.handle.net/2134/2756. 
This item was submitted to Loughborough's Institutional Repository by the author and is made available under the following Creative Commons Licence conditions.

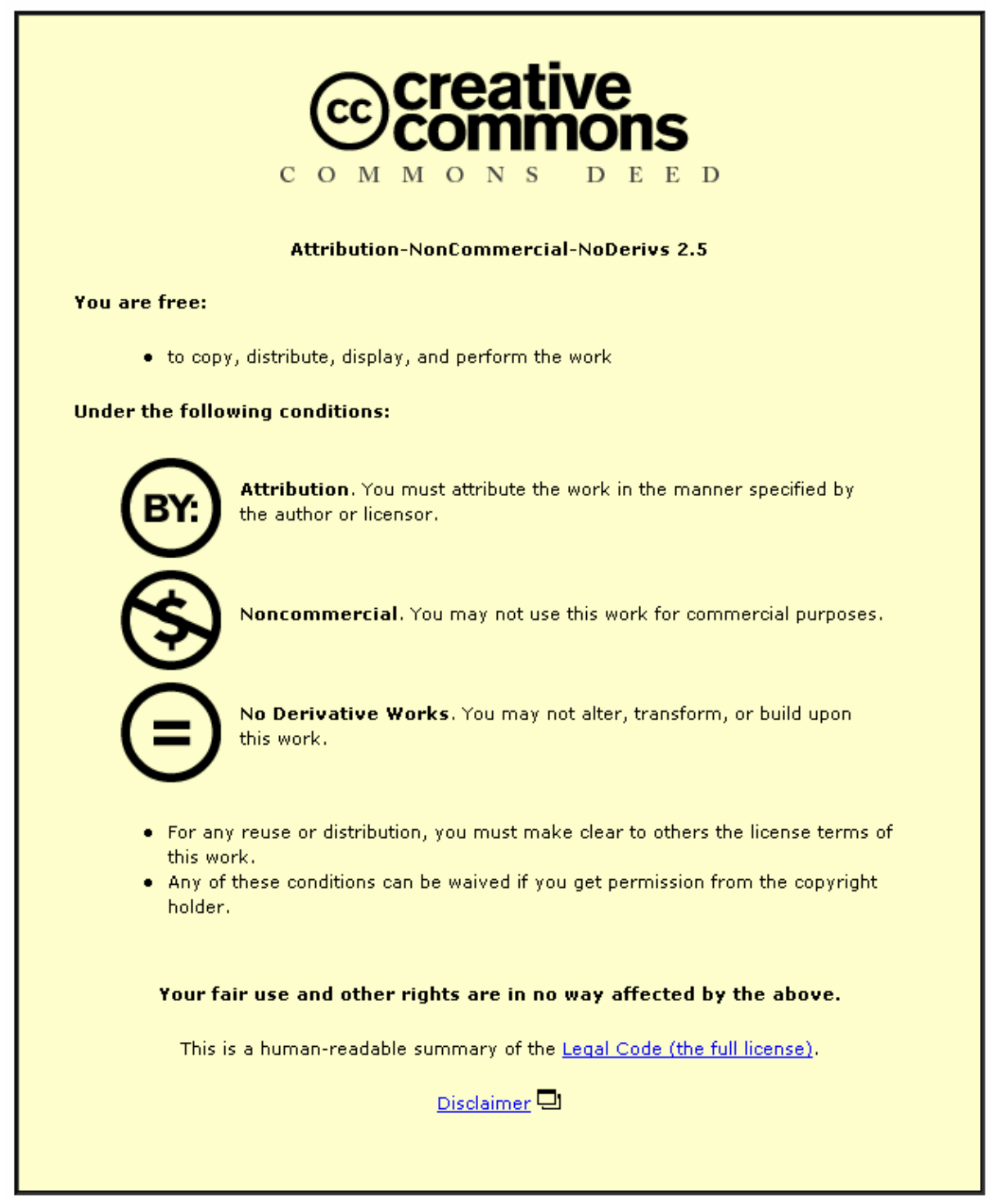

For the full text of this licence, please go to: http://creativecommons.org/licenses/by-nc-nd/2.5/ 
Loughborough University Institutional Repository paper. Author's own final version of the paper: RYLEY, T. and GJERSOE, N., 2006. Newspaper response to the Edinburgh congestion charging scheme proposals, Transport Policy 13 (1), pp. 66-73.

\title{
Newspaper response to the Edinburgh congestion charging proposals
}

\section{Tim Ryley}

T.J.Ryley@lboro.ac.uk

Department of Civil and Building Engineering, Loughborough University, Leicestershire. LE11 3TU

and

\section{Nathalia Gjersoe}

\section{n.l.gjersoe@bristol.ac.uk}

Department of Experimental Psychology, Bristol University, 8 Woodland Road, Bristol. BS8 1TN

\begin{abstract}
The media has been identified as a key player in the implementation of road pricing schemes, often against a background of low public and political acceptability. A media analysis framework was applied to the Edinburgh congestion charging proposals, to investigate newspaper response to the scheme. Newspaper coverage had been highly politicised and increasingly negative over the time period leading up to the referendum in February 2005, when the proposals were rejected by Edinburgh residents. The role of newspapers in reporting and making opinion, and the balance of positive and negative arguments towards the congestion charging proposals, are explored.
\end{abstract}


Loughborough University Institutional Repository paper. Author's own final version of the paper: RYLEY, T. and GJERSOE, N., 2006. Newspaper response to the Edinburgh congestion charging scheme proposals, Transport Policy 13 (1), pp. 66-73.

\section{Introduction}

In February 2005 the City of Edinburgh Council’s proposals for congestion charging in Edinburgh were rejected by city residents in a referendum (City of Edinburgh Council, 2005). Of those voting in the referendum, $74 \%$ voted against the proposals. With $69 \%$ of City of Edinburgh residents on the Electoral Register voting in the referendum, a high turnout was achieved. This paper investigates newspaper response to the Edinburgh congestion charging proposals prior to the referendum, over the time period of a European funded project, PRoGR€SS (June 1998 to May 2004).

Many urban road pricing proposals, including those for Edinburgh, have not been implemented. There is an increasing need to overcome low public and political acceptability of road pricing strategies (Schade and Schlag, 2003). Motorists tend to perceive congestion charging as a tax, both unfair that they have to pay for something that previously they had for free and coercive as they have few, if any, practical alternatives (Harrington et al, 1998). Acceptability of road pricing varies over time from the initial proposals through to the introduction of a scheme. It is acknowledged that acceptability falls before scheme introduction (when the public realise that they have to pay and do not like the design) but then rises after introduction (when the public can see that it works). Road pricing schemes in Norway have been implemented, despite acceptability values showing a more negative than positive opinion amongst the public at the time of scheme implementation (Tretvik, 2003).

Public acceptability towards the congestion charging proposals declined in Edinburgh over the four Public Consultation phases (Cain and Jones, 2002; Cain and Jones, 2003). In 1999, there was approximately 60\% support and 30\% opposition for the charging 
Loughborough University Institutional Repository paper. Author's own final version of the paper: RYLEY, T. and GJERSOE, N., 2006. Newspaper response to the Edinburgh congestion charging scheme proposals, Transport Policy 13 (1), pp. 66-73.

principle identified in Consultation Phase I ‘Edinburgh’s Transport Choices’. In 2002, the level of support had fallen, at the time of the Consultation Phase IV 'Have Your Say’. The option for a single, central cordon had marginal opposition amongst Edinburgh residents (43\% in favour, $47 \%$ against), whereas the option for two cordons (the option presented to the public in the referendum) had stronger opposition amongst Edinburgh residents (34\% in favour, 56\% against). As shown by the referendum result, support for congestion charging in Edinburgh declined further after Consultation Phase IV.

The media (newspapers, TV, radio) influences acceptability, and is often stated as a key player in the development of large transport planning projects such as urban road pricing schemes (Hårsman, 2003; Lyons, 2003). Media and communications discussion has been provided to overcome the negative press that can surround transport schemes (Jones, 2003): pro-actively engage key stakeholder groups at all stages of the scheme design and implementation process; take steps to encourage a culture change within the initiating organisation; and clarify and agree on the role of the elected member (local politician) in the process of scheme design, selection and implementation.

Lyons (2003) proposes three approaches for decision-makers and politicians to change the focus from the 'pain' to the 'gain' associated with transport project representations within the media. These approaches are to educate the public so they can see through the media hype, to work with the media and to ride the media storm. Riding a media storm has proved particularly difficult, but the example of the London congestion charging scheme shows that in certain circumstances a controversial transport project can be implemented in the face of a hostile press. 
Loughborough University Institutional Repository paper. Author's own final version of the paper: RYLEY, T. and GJERSOE, N., 2006. Newspaper response to the Edinburgh congestion charging scheme proposals, Transport Policy 13 (1), pp. 66-73.

This paper investigates newspaper response to the Edinburgh congestion charging proposals, as part of the urban road pricing project PRoGR€SS (Pricing ROad use for Greater Responsibility, Efficiency and Sustainability in cities). The PRoGR€SS project had an overall objective to demonstrate and evaluate the effectiveness and acceptance of integrated urban transport pricing schemes to achieve transport goals and raise revenue. Edinburgh was one of eight project sites developing and demonstrating road pricing schemes; the other cities were Bristol, Copenhagen, Genoa, Gothenburg, Helsinki, Rome and Trondheim. Media analysis across the eight sites is reported, along with other findings, in Deliverable 4.3 (PRoGR€SS, 2004).

The congestion charging scheme had been proposed by the City of Edinburgh Council (City of Edinburgh Council, 2004a; City of Edinburgh Council, 2004b), in accordance with The Transport (Scotland) Act 2001 (Scottish Parliament, 2001). The scheme consisted of two cordons and a £2 charge for inbound travel. A map of these cordons is shown in Figure 1. The charge would have applied between Monday and Friday, during the day $(7 \mathrm{am}-6.30 \mathrm{pm})$ for the inner cordon and morning peak for the outer cordon (7am - 10am). Vehicle exemptions included emergency service vehicles, motorcycles, local buses, Blue Badge holders (disabled) and City Car Club vehicles. City of Edinburgh Council area residents living outside the outer cordon were exempted from paying to cross the outer cordon. The importance of looking at the newspaper role in reporting or forming public opinion and attitudes was paramount, given the weight the Scottish Executive placed on the demonstration of clear public support for the scheme prior to implementation and the need to win a public referendum.

The primary aim of the Edinburgh proposals was to reduce congestion; a charging scheme would also offer a means of managing traffic levels and providing further 
Loughborough University Institutional Repository paper. Author's own final version of the paper: RYLEY, T. and GJERSOE, N., 2006. Newspaper response to the Edinburgh congestion charging scheme proposals, Transport Policy 13 (1), pp. 66-73.

transport investment. Charging can hit low income groups worst because of their higher marginal utility of money, but then revenue can arguably be used to improve alternative and cheaper forms of transport (Rajé, 2003).

Successfully implemented urban road pricing schemes, often with broader objectives than to reduce congestion, include Trondheim, Oslo, Bergen, Singapore and London. Of these, the central London congestion charging scheme, introduced in February 2003, is the most comparable to the proposed scheme in Edinburgh. London has been considered a success in terms of reducing congestion, the primary objective, although revenue has been lower than expected (Transport for London, 2004). In the year since introduction of the scheme, there have been reductions in traffic levels (15\%) and delays (30\%) within the charging zone. In the longer term, there are proposals for universal road pricing across the United Kingdom (Department for Transport, 2003; Department for Transport, 2004).

\section{Developing a media analysis framework for transport applications}

As asserted by Newbold (1995), the entire study of mass communications is based on the premise that the media does have significant effects upon opinions and attitudes. Katz and Lazarsfield (1995) present three major divisions within traditional mass media research. They are: research into the audience of a given communications message or medium; research enabling study of the language, logic and layout of communications messages; and research into the impact of mass communications. All three divisions ultimately look at the effect of the media influencing (and changing) opinions and attitudes of those receiving the communications. The focus of this paper is on the 
Loughborough University Institutional Repository paper. Author's own final version of the paper: RYLEY, T. and GJERSOE, N., 2006. Newspaper response to the Edinburgh congestion charging scheme proposals, Transport Policy 13 (1), pp. 66-73.

second of these three divisions, examining the communications messages of newspaper coverage relating to the Edinburgh congestion charging proposals.

There has been a recent increase in media analysis using transport applications. The importance of the media during the 2000 fuel tax protests was highlighted by Lyons and Chatterjee (2002), using historical and contemporary searches of newspaper archives. A comparative assessment of the press response to four proposed or implemented congestion charging schemes was undertaken by Krause (2004), using the terms “toll road" and "toll bridge" in newspaper text searches.

Media coverage of the London congestion charging scheme has been analysed in more detail by Gaber (2004). The study includes a chronology of events leading up to scheme implementation, a breakdown of positive and negative arguments within newspapers, an investigation into “scare stories”, and content analysis of direct quotations from individuals and organisations. The most rigorous methodological technique in Gaber's approach is content analysis, used in media research to study the language, logic and layout of communication messages (Katz and Lazarsfield, 1995). The analytical method of content analysis has also been utilised by Langmyhr (1997), to review the type and form of equity arguments that relate to congestion charging, as presented by different stakeholders in Norwegian newspapers (and official documentation and recorded proceedings).

Many of these media analysis techniques were applied to the Edinburgh congestion charging proposals: the development of a press archive, newspaper text searches, a chronology of events, a breakdown of positive and negative arguments within newspapers, and content analysis of the communications messages within newspapers. 
Loughborough University Institutional Repository paper. Author's own final version of the paper: RYLEY, T. and GJERSOE, N., 2006. Newspaper response to the Edinburgh congestion charging scheme proposals, Transport Policy 13 (1), pp. 66-73.

\section{Developing a newspaper analysis framework for the Edinburgh proposals}

As part of the PRoGR€SS project, a press archive of over 1,500 newspaper articles (between June 1998 and May 2004) was developed. Each article included at least one reference to the Edinburgh congestion charging proposals. The archive consisted of the following variables: article date; article headline; page number; article type (e.g. News, Comment, Letter); a summary of the main themes within the article; and a three-level star rating of the article's relevance to the Edinburgh congestion charging proposals.

In addition to the content of News stories within the press archive, the Letters and Comments sections were examined, to explore public and newspaper opinion as expressed in written form within newspapers. Letters written to the newspapers were categorized as to whether overall they were positive, negative or "other" (e.g. a factual letter or a letter with an equal split of positive and negative arguments) towards the congestion charging proposals. Newspaper opinion within the Comments pages of the Edinburgh Evening News during Consultation Phase IV was also examined; this Consultation Phase was the event over the time period of the press archive that generated the most newspaper coverage. A further aspect of the PRoGR€SS project was to consider whether the newspapers acted as opinion makers or opinion reporters in regard to the Edinburgh congestion charging proposals.

To quantify the argument direction of newspaper coverage, content analysis was performed on 165 News articles from the PRoGR€SS press archive (dating from January 2000 to June 2003). The articles selected were the most prominent, appearing on one of the first two pages of the two most represented newspapers within the press 
Loughborough University Institutional Repository paper. Author's own final version of the paper: RYLEY, T. and GJERSOE, N., 2006.

Newspaper response to the Edinburgh congestion charging scheme proposals, Transport Policy 13 (1), pp. 66-73.

archive, the Edinburgh Evening News and the Scotsman. The software package

NUDIST (Non-numerical Unstructured Data Indexing Searching and Theorizing), was used to conduct the content analysis. Each newspaper article was split into individual text units, defined as lines of text within the article separated by punctuation, the most detailed unit of analysis.

The key coding category within the content analysis was argument direction - whether newspaper article text units were positive or negative towards the proposals. Codes were also provided for mixed (positive and negative within the same text unit) and neutral (no opinion expressed, information imparted) arguments. Other coding categories were argument subject and the stakeholder expressing the argument (e.g. politician, member of the business community). Argument subject codes were developed from comments expressed by members of the public during Consultation Phase IV (Cain and Jones, 2002). The seven subject codes were: alternative solutions to congestion charging; charging scheme design; investment package; impacts of options; Consultation phases; political aspects of developing congestion charging scheme; and comparison of the Edinburgh scheme with other proposals.

\section{Newspaper response to the Edinburgh congestion charging proposals}

Media interest in the scheme grew over the time period of the PRoGR€SS project, reflected by a steady increase in the number of newspaper articles. Of the newspaper articles within the press archive, most were from the Edinburgh Evening News (952, 56\%). The next highest represented newspaper was the Scotsman (259, 15\%). Although the Edinburgh Evening News and the Scotsman are owned by the same 
Loughborough University Institutional Repository paper. Author's own final version of the paper: RYLEY, T. and GJERSOE, N., 2006. Newspaper response to the Edinburgh congestion charging scheme proposals, Transport Policy 13 (1), pp. 66-73.

company and often use the same information sources, they differ in format and style.

The Scotsman is a morning, Scotland-wide 'broadsheet' newspaper, whereas the Edinburgh Evening News is a local newspaper, more 'tabloid' in style. The scheme was often referred to as a "road toll”, even though the conventional image of a toll booth is out-dated and not relevant. Of the News story titles within the press archive, 45\% contained the word "toll”.

There were two Transport Convenors of the City of Edinburgh Council over the time period of the PRoGR€SS project, the Convenor being a key stakeholder in the congestion charging proposals. The identity of the Transport Convenor affected the nature of the congestion charging newspaper coverage; newspapers tended to personalise the proposals as linked to a particular individual, rather than the Labour Party, to which both Convenors belonged. Some of the opposition political parties, in particular the Conservative Party and the Scottish Nationalist Party (SNP), staged their own publicity stunts and photo-calls to present negative messages against the congestion charging proposals. Both parties, at different times (the Conservative party in January 2001, the SNP in June 2002), used a Dick Turpin publicity stunt, considering the congestion charging proposals to be "highway robbery".

The views of politicians from surrounding Local Authorities were also represented in the newspaper coverage. West Lothian, Midlothian and Fife Councils were particularly vociferous in opposing the scheme, in response to exemptions that had been given to City of Edinburgh Council residents living outside the outer cordon in September 2003. Interest groups also expressed their views in the newspaper coverage. The Edinburgh Evening News often used the Automobile Association to present the motorist's view, against the congestion charging proposals. Some environmental campaigning groups, 
Loughborough University Institutional Repository paper. Author's own final version of the paper: RYLEY, T. and GJERSOE, N., 2006. Newspaper response to the Edinburgh congestion charging scheme proposals, Transport Policy 13 (1), pp. 66-73.

such as Friends of the Earth and TRANSFORM Scotland, used the letters page to

express their support of the congestion charging proposals. Business and retail

representatives, including the Edinburgh Chamber of Commerce and the Scottish Retail

Consortium, also made comments.

Of the articles within the press archive, 30\% were Letters written to the newspapers.

Most of these Letters (83\%) had been written to the Edinburgh Evening News. From

the argument categories of the overall tone of the letters, more were negative (55\%)

than positive (22\%); the remainder had a mixed opinion towards the proposals. Half of

the positive arguments were written by the City of Edinburgh Council Convenor for

Transport in response to a previous news story or letter. Of the letter writers to the

Edinburgh Evening News, regular writers (over four letters) were more negative than occasional writers.

Analysis of the Comments section during Consultation Phase IV also illustrates the negative slant to the newspaper coverage. At the time of consultation launch, the Comments section of the Edinburgh Evening News (11 ${ }^{\text {th }}$ June 2002) stated that it was crucial that the "public consultation gives everyone the facts and stresses the options clearly”. Over the remainder of the consultation phase (until the publication of the report at the end of September 2002 - Cain and Jones, 2002) the Comments section of the newspaper was critical concerning the following aspects of the proposals:

- consultation leaflets should be distributed to every home $\left(18^{\text {th }}\right.$ July, $19^{\text {th }}$ September);

- the consultation period (for the public to take part) should be extended from the end of July until the end of September ( $18^{\text {th }}$ July); 
Loughborough University Institutional Repository paper. Author's own final version of the paper: RYLEY, T. and GJERSOE, N., 2006. Newspaper response to the Edinburgh congestion charging scheme proposals, Transport Policy 13 (1), pp. 66-73.

- motorists need to be given a viable alternative to the private car before the punitive charges are introduced ( $29^{\text {th }}$ July);

- the low public response rate of 12,000 in a city of 450,000 ( $30^{\text {th }}$ August);

- a Conservative councillor victory in a Balerno by-election could be linked to the congestion charging proposals $\left(13^{\text {th }}\right.$ September);

- members of the general public had "swamped" the exercise with multiple responses $\left(19^{\text {th }}\right.$ September, $23^{\text {rd }}$ September $)$;

- the way the results had been “weighted” $\left(19^{\text {th }}\right.$ September, $23^{\text {rd }}$ September $)$;

- a report on the retail and economic impacts of the proposals was not available before the Council decision on scheme development $\left(25^{\text {th }}\right.$ September, $1^{\text {st }}$ October); and

- $\quad$ the permanency of the proposed scheme ( $1^{\text {st }}$ October $)$.

Newspaper opinion was consistently negative towards Consultation Phase IV, as expressed within the Comments section of the Edinburgh Evening News. The final Comments section in the Edinburgh Evening News ( $8^{\text {th }}$ October), relating to Consultation Phase IV, stated that in response to their two main concerns (public transport improvement before scheme, consultation flawed), the "Council has listened" (to the newspaper). The Labour group had "agreed to hold a referendum and to explore whether other public transport improvements could be introduced before road tolls”. The Edinburgh Evening News, therefore, considered itself to have a major influence upon political decision-making towards the congestion charging proposals. 
Loughborough University Institutional Repository paper. Author's own final version of the paper: RYLEY, T. and GJERSOE, N., 2006. Newspaper response to the Edinburgh congestion charging scheme proposals, Transport Policy 13 (1), pp. 66-73.

\section{Argument direction within news stories}

Using content analysis, argument direction within News articles written between January 2000 and June 2003 was quantified. Of the 165 news articles upon which the content analysis was performed, 124 were from the Edinburgh Evening News and 41 were from the Scotsman. The analysis concerns 8,946 text units, an average of 54 text units per newspaper article. Most text units were classified as either positive (34\%) or negative (40\%). A similar proportion of positive and mixed arguments were presented in both newspapers, but a distinct difference in negative (12\% more negative in the Edinburgh Evening News) and neutral (7\% more neutral in the Scotsman) arguments.

Key events affecting the development of congestion charging proposals in Edinburgh, over the time period of the newspapers within the content analysis are shown in Table 1. They comprise political (e.g. elections, key politician appointments) and congestion charging milestones (e.g. consultation phases, passing of legislation). Figure 2, a graph of text units split by argument direction, can be compared against the key events outlined in Table 1 and the four primary argument subjects in Table 2. Newspaper coverage of new articles in the Edinburgh Evening News and the Scotsman increased in mid 2002, coinciding with the start of Consultation Phase IV. An increase in neutral / fact based arguments reflects information provided by the City of Edinburgh Council to the newspapers via press releases at the start of the consultation phase.

There were more negative than positive arguments during the four month time period of the Consultation Phase IV (from June to September 2002). During the third Quarter of 2002 over half (53\%) of the 1,839 text units were negative arguments. Arguments relating to consultation phases (in Table 2) within the content analysis were more 
Loughborough University Institutional Repository paper. Author's own final version of the paper: RYLEY, T. and GJERSOE, N., 2006. Newspaper response to the Edinburgh congestion charging scheme proposals, Transport Policy 13 (1), pp. 66-73.

negative (47\%) than positive (23\%). Those articles particularly negative were examined (over $75 \%$ of the text units were negative arguments). Article headlines of the particularly negative articles illustrate the role of the Edinburgh Evening News criticising the consultation (“City’s road tolls poll is a sham”, $2^{\text {nd }}$ August 2003) and gathering support against the congestion charge proposals ("Road toll protesters claim more support”, $2^{\text {nd }}$ August 2003). Critics of the proposals within this subset of Edinburgh Evening News articles included the Scottish National Party, a Liberal Democrat MSP, a former Labour minister, the Scottish Conservative Party and the Cockburn Association (an Edinburgh heritage trust organisation). As shown previously, examining the Comments section of the Edinburgh Evening News during Consultation Phase IV, it appears that the newspaper itself had a role reinforcing the negative arguments associated with the proposals.

Conversely, the newspaper coverage was more positive during the first Quarter of 2003 (713 positive text units, 338 negative). The Edinburgh Evening News carried a story on a speech by the Convenor for Transport at the City of Edinburgh Council on the air quality and health improvements in Edinburgh as a result of congestion charging $\left(12^{\text {th }}\right.$ February 2003, $13^{\text {th }}$ February 2003). The Scotsman had wider positive news coverage, focusing on the February 2003 successful introduction of congestion charging in London. They reported on other cities that could implement schemes similar to the congestion charging in London (18 ${ }^{\text {th }}$ February 2003) and a survey of business executives supporting the scheme in London (1 $7^{\text {th }}$ March 2003). It is the comparison with other proposals (principally the London scheme) that represents the most positive (54\% positive arguments, 21\% negative) of the four primary argument categories (Table 2). 
Loughborough University Institutional Repository paper. Author's own final version of the paper: RYLEY, T. and GJERSOE, N., 2006. Newspaper response to the Edinburgh congestion charging scheme proposals, Transport Policy 13 (1), pp. 66-73.

Of the four primary argument subjects in Table 2, the political arguments were particularly negative (69\% negative arguments, 23\% positive). Approximately half (52\% of all text units) of the stakeholders represented in the newspaper articles were politicians. As shown previously, the newspaper coverage has focused primarily on the political aspects of scheme development, with widespread coverage of opinion from the Transport Convenor and various opposition politicians. The proportion is higher for the Edinburgh Evening News (55\%). Much of the remainder is attributable to the reporter or no citation (24\%). Other stakeholders (public opinion, business opinion, interest groups) were represented and tended to be more negative than positive, but constituted a small proportion of text units (none of these stakeholders contributed more that $10 \%$ of the text units).

Most of the argument subjects (59\%) related directly to the congestion charge scheme proposals (in Table 2). These 5,162 text units were split into sub-categories and ranked; these categories are shown in Table 3. The overall positive / negative split was similar for the actual design of congestion charging scheme design (37\% / 36\%). The split for the most popular category, setting up a system for the introduction of congestion charging was more positive than negative (47\% / 41\%). This primarily concerned debate over whether public transport improvements would be in place before implementation of the proposed scheme. Arguments consisted of assurances from scheme proponents that there would be "significant public transport improvements" in place first (Edinburgh Evening News: $20^{\text {th }}$ January 2001, $4^{\text {th }}$ September 2001) and criticisms from scheme opponents that there would not be enough public transport alternatives prior to implementation (Edinburgh Evening News: $20^{\text {th }}$ June 2002, $4^{\text {th }}$ July 2002). 
Loughborough University Institutional Repository paper. Author's own final version of the paper: RYLEY, T. and GJERSOE, N., 2006. Newspaper response to the Edinburgh congestion charging scheme proposals, Transport Policy 13 (1), pp. 66-73.

The split for the remaining sub-categories tended to be one-sided (either positive or negative). The most positive of the sub-categories was the role of the alternative transport systems (75\% of arguments were positive). The investment package, particularly the introduction of trams, was used as a major selling point by scheme proponents. This included articles stating boldly and positively that trams were at the “top of the Council’s wish-list” (Edinburgh Evening News, $5^{\text {th }}$ June 2000) and a “number one transport priority” (Edinburgh Evening News, $4^{\text {th }}$ October 2000). A $£ 375$ million funding package was announced for two tram lines in Edinburgh (Scotsman, $5^{\text {th }}$ March 2003), but not dependent on implementation of the congestion charging proposals. A third tram line was dependent on the congestion charging proposals, but the announcement of Scottish Executive funding for the first two tram lines meant there was less of a link between congestion charging and the provision of a tram system.

The most negative of the sub-categories related to the use of alternative sources, either taxes already paid (e.g. Road tax - Scotsman, $13^{\text {th }}$ June 2002) or central government funding (e.g. Scottish Executive should pay - Edinburgh Evening News, $27^{\text {th }}$ July 2002), to fund transport improvements ( $82 \%$ of arguments were negative). The equity arguments were also particularly negative (72\% of arguments were negative). Equity, in terms of the effect of congestion charging on low income groups, was not a major issue in the media. Equity, as reported in the newspapers, related to the fairness of cordon location, particularly the outer cordon. Opposition to the cordons was expressed from surrounding Local Authorities relating to the fairness of the cordons (Edinburgh Evening News, $29^{\text {th }}$ November 2001; Scotsman, $12^{\text {th }}$ June 2002). Such opposition increased after September 2003 (and the time period of the content analysis), when exemptions were given to City of Edinburgh Council residents living outside the outer cordon. 
Loughborough University Institutional Repository paper. Author's own final version of the paper: RYLEY, T. and GJERSOE, N., 2006. Newspaper response to the Edinburgh congestion charging scheme proposals, Transport Policy 13 (1), pp. 66-73.

\section{Discussion and conclusions}

The aim of the media research within the PRoGR€SS project was to investigate the role of newspapers in the development of charging proposals in Edinburgh. Of the newspapers examined, the local newspaper, the Edinburgh Evening News, presented a campaigning and more negative approach to the proposals. Newspaper coverage of the congestion charging proposals increased over time, swinging between positive and negative coverage, although overall it was more negative than positive (and increasingly so since the end of the PRoGR€SS project). The introduction of congestion charging in London represented a period of positive coverage, but the Consultation Phase IV 'Have Your Say’ was more influential and negative towards the proposals.

Whether desirable or not, the political process was central to the media's interest in the development of the Edinburgh congestion charging proposals. Of the stakeholders represented within the content analysis, politicians had by far the greatest coverage. The political person responsible, therefore, had an important role in communicating the scheme to the media, in this case the Transport Convenor of the City of Edinburgh Council. This confirms findings from Krause (2004) of a project champion as crucial to successful implement of a congestion charging scheme (viz. the role of the Mayor Ken Livingstone in the London congestion charging scheme).

Although arguments within the newspaper articles tended to be more negative than positive, often due to the politicised nature of the proposals, arguments relating to the actual scheme design were finely balanced. The positive arguments related to the 'carrot' of the investment package such as a new tram system, whereas the negative 
Loughborough University Institutional Repository paper. Author's own final version of the paper: RYLEY, T. and GJERSOE, N., 2006. Newspaper response to the Edinburgh congestion charging scheme proposals, Transport Policy 13 (1), pp. 66-73.

arguments related to financial 'sticks'. It appears that decisions to fund two tram lines separately from the congestion charging scheme and to provide exemptions for City of Edinburgh residents outside the outer cordon encouraged opposition to the congestion charging proposals.

One aspect of the PRoGR€SS project was to consider whether the newspapers acted as opinion reporters or opinion makers in regard to the Edinburgh congestion charging proposals. Press Launches (at the start of Consultation phases) and Press Releases were used by the City of Edinburgh Council to inform the media. Most newspaper articles directly reported this information within News articles. As shown by analysis of the Letters page within newspapers, letters written to newspapers were also used to report public and political opinion towards the congestion charging proposals.

However, the newspapers clearly added their own interpretation and sources of information to the News articles. As illustrated in the analysis, newspapers also acted as opinion makers through their bias in a story (e.g. using the term "road toll”) and the Comments section (e.g. during Consultation Phase IV). Although there were instances of the newspapers both reporting and making opinion towards the proposals, arguably more emphasis was placed on the opinion making role of newspapers. Gaber (2004) concludes that the majority of the media failed to give a balanced view about the issues surrounding the introduction of the London scheme. The same could be said of the coverage in Edinburgh.

There are implications for policy makers elsewhere considering the introduction of controversial transport projects such as urban road pricing. An understanding of how to deal with the local and national media seems a pre-requisite to successful delivery. In 
Loughborough University Institutional Repository paper. Author's own final version of the paper: RYLEY, T. and GJERSOE, N., 2006.

Newspaper response to the Edinburgh congestion charging scheme proposals, Transport Policy 13 (1), pp. 66-73.

particular, as shown in this paper, policy makers need to understand the political nature

of media coverage and the likely split of arguments presented by the media to the general public. Emphasis should be made on the 'carrots' rather than the 'sticks' associated with such projects.

Much work relating to transport and the media, including this study, has focused on congestion charging applications and communications messages. It is recommended that further transport and the media research uses the other two methodological approaches within Katz and Lazarsfield (1995): research into the audience of transport communications messages and into the impact of transport communications messages. There is an evident research gap in analysing the direct links between newspaper content and public opinion.

\section{Acknowledgements}

This work was undertaken as part of the PRoGR€SS project, funded by the European commission DG-TREN (see www.progress-project.org for further details). The authors would like to thank Professor Christiane Bielefeldt at the Transport Research Institute, Napier University and staff at Transport Initiatives Edinburgh Ltd for their assistance in the development of the press archive and the content analysis. They would also like to thank Tina Seidel of Dresden University of Technology for her comments on the paper. The primary source for obtaining the articles was the Council Information Centre within the City of Edinburgh Council. 
Loughborough University Institutional Repository paper. Author's own final version of the paper: RYLEY, T. and GJERSOE, N., 2006. Newspaper response to the Edinburgh congestion charging scheme proposals, Transport Policy 13 (1), pp. 66-73.

\section{References}

Cain, A. and Jones P.M. (2002) Public Consultation Strategy - Phase IV. Strategic Regional Consultation, PRoGR€SS Report, September 2002.

Cain, A. and Jones P.M. (2003) 'Using public consultation as an input to developing Edinburgh’s congestion-charging-based transport strategy', Transportation Research Record 1839, pp. 89-97.

City of Edinburgh Council. (2004a) The Integrated Transport Initiative for Edinburgh and South East Scotland proposed congestion charging scheme, Statement of Case, Transport Initiatives Edinburgh Ltd and the City of Edinburgh Council (Download T163 from iti.tiedinburgh.co.uk - accessed $26^{\text {th }}$ April 2005).

City of Edinburgh Council. (2004b) Local Transport Strategy 2004-2007, The City of Edinburgh Council, March 2004 [Download T7 from iti.tiedinburgh.co.uk - accessed $26^{\text {th }}$ April 2005].

City of Edinburgh Council. (2005) Council positive on transport future. Press release on the referendum result, $22^{\text {nd }}$ February 2005.

[http://www.edinburgh.gov.uk/transportedinburgh/Referendum/index.html - accessed $26^{\text {th }}$ April 2005]

Department for Transport. (2003) Managing our roads, Department for Transport discussion paper, Department for Transport, London. 
Loughborough University Institutional Repository paper. Author's own final version of the paper: RYLEY, T. and GJERSOE, N., 2006. Newspaper response to the Edinburgh congestion charging scheme proposals, Transport Policy 13 (1), pp. 66-73.

Department for Transport. (2004) Feasibility study of road pricing in the UK - report, Department for Transport, London.

Gaber, I. (2004) Driven to distraction: an analysis of the media's coverage of the introduction of the London congestion charge, Unit for Journalism Research, Goldsmiths College, University of London.

Harrington, W., Krupnick, A. J. and Alberini, A. (1998) Overcoming Public Aversion to Congestion Pricing, Discussion Paper 98-27, Resources for the Future, Washington DC.

Hårsman, B. (2003) 'Success and failure: experience from cities’, in Schade, J. and Schlag, B. (ed) Acceptability of transport pricing strategies, Elsevier, Oxford.

Jones, P. (2003) ‘Acceptability of road user charging: meeting the challenge’, in Schade, J. and Schlag, B. (ed) Acceptability of transport pricing strategies, Elsevier, Oxford.

Katz, E. and Lazarsfield, P. F. (1995) 'Between media and mass / the part played by people / the two-step flow of communication', in Boyd-Barrett, O. and Newbold, C. (ed) Approaches to media - a reader, Arnold, London.

Krause, H.M. (2004) Media's role in value pricing implementation. Paper presented at Annual Meeting of the Transportation Research Board, Washington DC, January 2004.

Langmyhr, T. (1997) 'Managing Equity - The Case of Road Pricing', Transport Policy 4 (1), pp. 25-39. 
Loughborough University Institutional Repository paper. Author's own final version of the paper: RYLEY, T. and GJERSOE, N., 2006. Newspaper response to the Edinburgh congestion charging scheme proposals, Transport Policy 13 (1), pp. 66-73.

Lyons, G. (2003) Transport and society, Inaugral Lecture, University for Transport and Society, 1 May 2003.

Lyons, G. and Chatterjee, K. (eds) (2002) Transport lessons from the fuel tax protests of 2000, Ashgate.

Newbold, C. (1995) ‘The media effects tradition’, in Boyd-Barrett, O. and Newbold, C. (ed) Approaches to media - a reader, Arnold, London.

PRoGR€SS (2004) Social and political issues, Deliverable 4.3 of PRoGR€SS (Pricing ROad use for Greater Responsibility, Efficiency and Sustainability in cities) project, European Commission [www.urban-pricing.net - accessed $26^{\text {th }}$ April 2005].

Rajé, F. (2003) The impact of transport on social exclusion processes with specific emphasis on road user charging. Transport Policy, 10 (4), pp 321-338.

Schade, J. and Schlag, B. (2003) Acceptability of transport pricing strategies, Elsevier, Oxford.

Scottish Parliament. (2001) Transport (Scotland) Act 2001, The Stationery Office Ltd. [http://www.scotlandlegislation.hmso.gov.uk/legislation/scotland/acts2001/20010002.htm - accessed $26^{\text {th }}$ April 2005] 
Loughborough University Institutional Repository paper. Author's own final version of the paper: RYLEY, T. and GJERSOE, N., 2006.

Newspaper response to the Edinburgh congestion charging scheme proposals, Transport Policy 13 (1), pp. 66-73.

Tretvik, T. (2003) 'Urban road pricing in Norway: public acceptability and travel

behaviour', in Schade, J. and Schlag, B. (ed) Acceptability of transport pricing

strategies, Elsevier, Oxford.

Transport for London. (2004) Update on scheme impacts and operations, February 2004. Transport for London. 
Loughborough University Institutional Repository paper. Author's own final version of the paper: RYLEY, T. and GJERSOE, N., 2006. Newspaper response to the Edinburgh congestion charging scheme proposals, Transport Policy 13 (1), pp. 66-73.

Figure 1. A map of the outer and inner cordons for the proposed Edinburgh congestion charging scheme
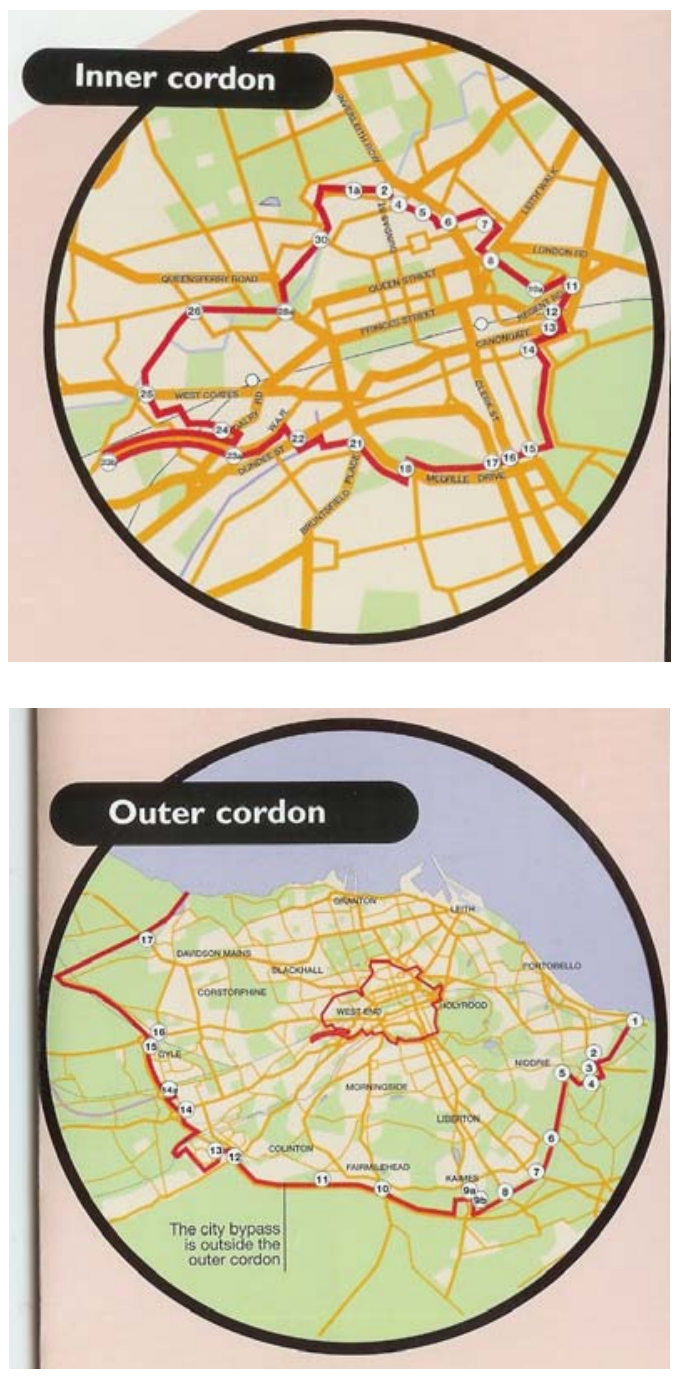

The map of the inner and outer cordons for the proposed Edinburgh congestion charging scheme, were taken from the Edinburgh referendum leaflet and reproduced with the permission of the City of Edinburgh Council 
Loughborough University Institutional Repository paper. Author's own final version of the paper: RYLEY, T. and GJERSOE, N., 2006. Newspaper response to the Edinburgh congestion charging scheme proposals, Transport Policy 13 (1), pp. 66-73.

Figure 2. A graph of the text units in newspaper articles between January 2000 and June 2003

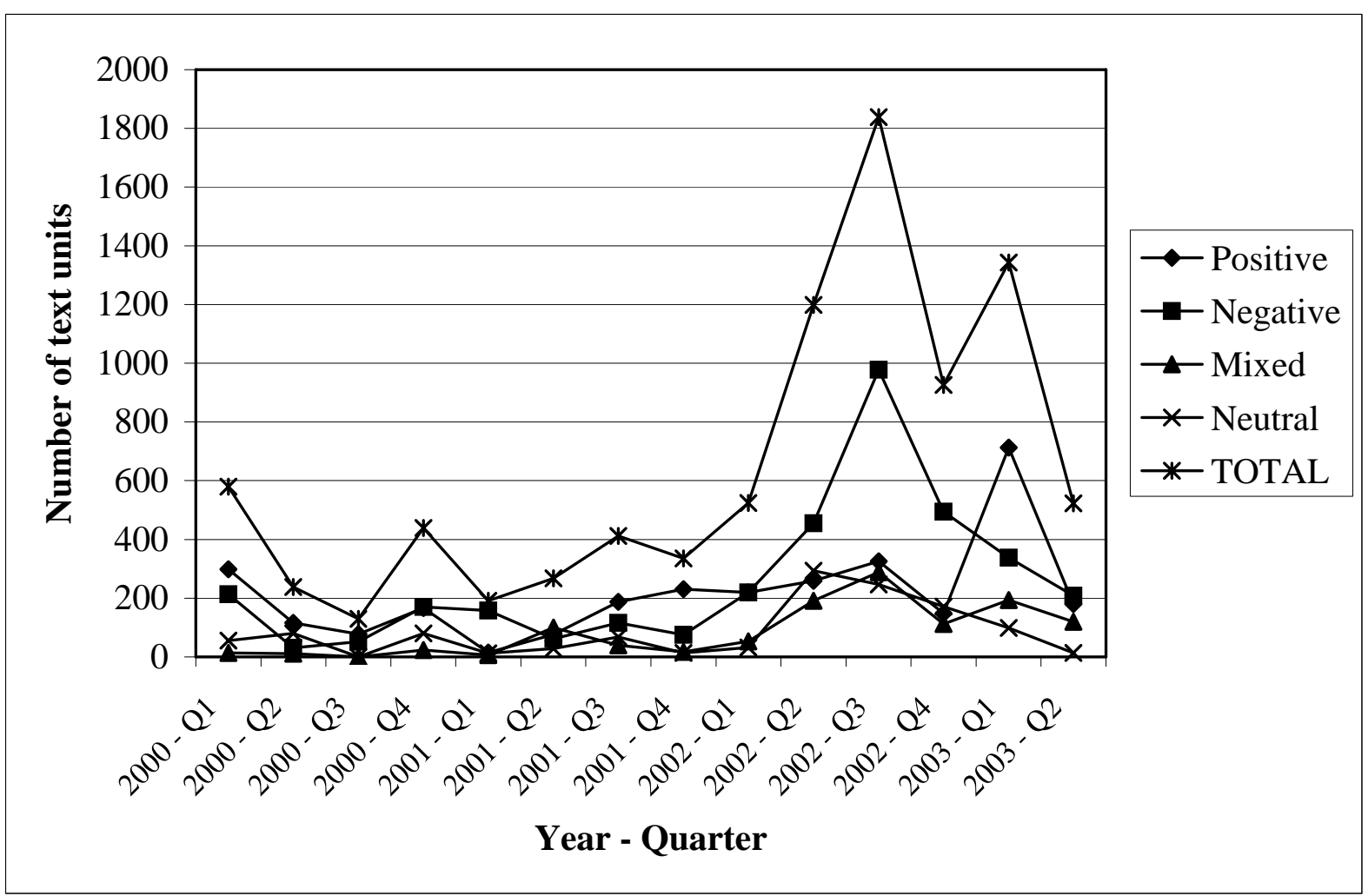


Loughborough University Institutional Repository paper. Author's own final version of the paper: RYLEY, T. and GJERSOE, N., 2006.

Newspaper response to the Edinburgh congestion charging scheme proposals, Transport Policy 13 (1), pp. 66-73.

\section{Table 1. Key events in the development of congestion charging in Edinburgh over the timescale of the content analysis (January 2000 - June 2003)}

Date Event

14.2.00 Report submitted to the City of Edinburgh Council Transportation Committee on Public Consultation Phase I "Edinburgh Transport Choices” (conducted Autumn 1999), 18,778 questionnaires returned.

6.6.00 Scottish Executive published Integrated Transport Bill.

22.8.00 Consultation Phase II begins: focus groups and interviews (512 Citizen's Panel and 200 non-motorists).

30.10.00 City of Edinburgh Council Local Transport Strategy submitted to the Scottish Executive.

7.11.00 Transport Bill by Scottish Parliament. Dropped workplace levy option and road user charging on Scottish Trunk Roads.

19.12.00 Cllr Mark Lazarowicz, Executive Member for Transport at the City of Edinburgh Council goes public with details of his preferred scheme.

21.12.00 Initial development of a charging and investment package - Scottish Executive grant approval in principle.

25.1.01 Royal Assent for Transport Bill - Transport (Scotland) Act 2000.

31.5.01 Andrew Burns replaces Mark Lazarowicz as Executive Member for Transport (Transport Convenor) at the City of Edinburgh Council.

7.6.01 UK General Elections.

11.9.01 "New Transport Initiative (NTI) - New Steps" presented to Council Executive, concerning major transport improvements and possible congestion charging scheme

Consultation Phase III begins: Regional market research (16 focus groups and 1,341 questionnaires).

22.10.01 City of Edinburgh Council receive award £12.5 million from Scottish Executive Public Transport Fund for NTI projects.

30.10.01 Submission for approval to Scottish Executive by City of Edinburgh Council: "Development of an Integrated Transport Initiative for Edinburgh and South East Scotland".

21.3.02 Scottish Executive grants approval to Edinburgh congestion charging scheme, subject to public backing.

30.4.02 Transport Initiatives Edinburgh Ltd (TIE) formed as a private limited company, wholly owned by the City of Edinburgh Council.

12.6.02 Consultation Phase IV begins: "Have Your Say" regional consultation (until 31 July 2002 - 18,780 responses from members of the public and 266 from organisations).

18.9.02 Full Council debate on the Integrated Transport Initiatives (ITI - note ITI replaced term NTI) report for Edinburgh and South East Scotland.

30.9.02 Transport Initiatives Edinburgh Ltd (TIE) submit report on Approval in Principle to Scottish Executive and City of Edinburgh Council.

18.12.02 Scottish Executive grants Approval in Principle to Edinburgh congestion charging scheme.

17.2.03 London congestion charging scheme starts. Impacts and effects monitored during development of Edinburgh scheme proposals.

1.5.03 Local and Scottish Parliament elections. 
Loughborough University Institutional Repository paper. Author's own final version of the paper: RYLEY, T. and GJERSOE, N., 2006. Newspaper response to the Edinburgh congestion charging scheme proposals, Transport Policy 13 (1), pp. 66-73.

Table 2. Text units of the News articles: Direction of argument split by argument subject

\begin{tabular}{|c|c|c|c|c|c|c|}
\hline Argument subject & Positive & Negative & Mixed & Neutral & \multicolumn{2}{|l|}{ Total } \\
\hline Congestion & 1905 & 1875 & 714 & 668 & \multirow[t]{2}{*}{5162} & \multirow[t]{2}{*}{$(57.7 \%)$} \\
\hline charging proposals & $36.9 \%$ & $36.3 \%$ & $13.8 \%$ & $12.9 \%$ & & \\
\hline Consultation & 242 & 493 & 153 & 152 & \multirow[t]{2}{*}{1040} & \multirow[t]{2}{*}{$(11.6 \%)$} \\
\hline phases & $23.3 \%$ & $47.4 \%$ & $14.7 \%$ & $14.6 \%$ & & \\
\hline \multirow[t]{2}{*}{ Political aspects } & 182 & 549 & 40 & 21 & \multirow[t]{2}{*}{792} & \multirow[t]{2}{*}{$(8.9 \%)$} \\
\hline & $23.0 \%$ & $69.3 \%$ & $5.1 \%$ & $2.7 \%$ & & \\
\hline \multirow{2}{*}{$\begin{array}{l}\text { Comparison with } \\
\text { other proposals }\end{array}$} & 420 & 160 & 157 & 41 & \multirow[t]{2}{*}{778} & \multirow[t]{2}{*}{$(8.7 \%)$} \\
\hline & $54.0 \%$ & $20.6 \%$ & $20.2 \%$ & $5.3 \%$ & & \\
\hline \multirow[t]{2}{*}{ Other } & 264 & 495 & 104 & 311 & \multirow[t]{2}{*}{1174} & \multirow[t]{2}{*}{$(13.1 \%)$} \\
\hline & $22.5 \%$ & $42.2 \%$ & $8.9 \%$ & $26.5 \%$ & & \\
\hline \multirow[t]{2}{*}{ TOTAL } & 3013 & 3572 & 1168 & 1193 & 8946 & \multirow{2}{*}{$(100 \%)$} \\
\hline & $33.7 \%$ & $39.9 \%$ & $13.1 \%$ & $13.3 \%$ & $100.0 \%$ & \\
\hline
\end{tabular}


Loughborough University Institutional Repository paper. Author's own final version of the paper: RYLEY, T. and GJERSOE, N., 2006. Newspaper response to the Edinburgh congestion charging scheme proposals, Transport Policy 13 (1), pp. 66-73.

Table 3. Text units of the News articles relating directly to the proposals: Direction of argument split by congestion charging argument subject

\begin{tabular}{|c|c|c|c|c|c|c|}
\hline Argument subject & Positive & Negative & Mixed & Neutral & \multicolumn{2}{|l|}{ TOTAL } \\
\hline Charging scheme design: & 523 & 461 & 92 & 38 & \multirow[t]{2}{*}{1114} & \multirow[t]{2}{*}{$(21.6 \%)$} \\
\hline Setting up & $46.9 \%$ & $41.4 \%$ & $8.3 \%$ & $3.4 \%$ & & \\
\hline Impacts of options: & 129 & 375 & 95 & 4 & \multirow[t]{2}{*}{603} & \multirow[t]{2}{*}{$(11.7 \%)$} \\
\hline Business Impact & $21.4 \%$ & $62.2 \%$ & $15.8 \%$ & $0.7 \%$ & & \\
\hline Impacts of options: & 22 & 377 & 63 & 61 & \multirow[t]{2}{*}{523} & \multirow[t]{2}{*}{$(10.1 \%)$} \\
\hline Fairness / equity & $4.2 \%$ & $72.1 \%$ & $12.0 \%$ & $11.7 \%$ & & \\
\hline Impacts of options: & 316 & 94 & 44 & 6 & \multirow[t]{2}{*}{460} & \multirow[t]{2}{*}{$(8.9 \%)$} \\
\hline Congestion & $68.7 \%$ & $20.4 \%$ & $9.6 \%$ & $1.3 \%$ & & \\
\hline Alternative solution: & 33 & 272 & 14 & 12 & \multirow[t]{2}{*}{331} & \multirow[t]{2}{*}{$(6.4 \%)$} \\
\hline $\begin{array}{l}\text { Use other taxes / just } \\
\text { another tax }\end{array}$ & $10.0 \%$ & $82.2 \%$ & $4.2 \%$ & $3.6 \%$ & & \\
\hline Charging scheme design: & 31 & 125 & 12 & 110 & \multirow[t]{2}{*}{278} & \multirow[t]{2}{*}{$(5.4 \%)$} \\
\hline Technology & $11.2 \%$ & $45.0 \%$ & $4.3 \%$ & $39.6 \%$ & & \\
\hline Investment package: & 207 & 37 & 29 & 4 & \multirow[t]{2}{*}{277} & \multirow[t]{2}{*}{$(5.4 \%)$} \\
\hline $\begin{array}{l}\text { Alternative transport } \\
\text { systems }\end{array}$ & $74.7 \%$ & $13.4 \%$ & $10.5 \%$ & $1.4 \%$ & & \\
\hline \multirow[t]{2}{*}{ Other } & 644 & 134 & 365 & 433 & \multirow[t]{2}{*}{1576} & \multirow[t]{2}{*}{$(30.5 \%)$} \\
\hline & $40.9 \%$ & $8.5 \%$ & $23.2 \%$ & $27.5 \%$ & & \\
\hline \multirow[t]{2}{*}{ TOTAL } & 1905 & 1875 & 714 & 668 & 5162 & \multirow[t]{2}{*}{$(100 \%)$} \\
\hline & $36.9 \%$ & $36.3 \%$ & $13.8 \%$ & $12.9 \%$ & $100.0 \%$ & \\
\hline
\end{tabular}

Note: Argument subject categories are presented in rank order of the total number of text units (largest first). Subject categories with less than 250 text units were put into the 'Other' subject category 